\title{
Fencing and Forest Conservation: Attitudes of Local People Living Adjacent to Eastern Slopes of Mount Kenya
}

\author{
Mugambi David Mbuba \\ Department of Environmental Studies and Resource Development, Faculty of Agriculture and Environmental Studies, Chuka University, \\ Chuka, Kenya
}

Email address:

mugambis@yahoo.com

\section{To cite this article:}

Mugambi David Mbuba. Fencing and Forest Conservation: Attitudes of Local People Living Adjacent to Eastern Slopes of Mount Kenya. International Journal of Natural Resource Ecology and Management. Vol. 4, No. 1, 2019, pp. 1-6. doi: 10.11648/j.ijnrem.20190401.11

Received: December 13, 2018; Accepted: January 10, 2019; Published: January 30, 2019

\begin{abstract}
This study was carried out to assess local people attitudes on fencing and conservation management of Mount Kenya Forest. A random sampling technique was used in administering semi structured questionnaires to 100 households living adjacent to the forest. Secondary sources and key informants provided additional information through interviews. Data was analyzed using descriptive statistics and creation of themes. From the findings $57 \%$ of the respondents were male and $43 \%$ were female. Age distribution revealed that $6 \%$ of the respondents were between the ages of $21-30$ years; $30 \%$ between the ages of $31-40$ years; $24 \%$ between the ages of $41-50$ years; $19 \%$ were aged 60 and above. The results showed that local communities are deriving myriad benefits from the forest which include; fuel wood, timber, honey, fruits, medicinal plants and water for community irrigation projects. Findings shows that seventy six percent (76\%) of the respondents' supported forest conservation while $24 \%$ supported de-gazettement of forest to create farmlands. Fence installation has led to reduced cases of crop and destruction of property and death/injury of livestock. The results further revealed that forest illegal activities have significantly declined, citing few cases of illegal harvesting of hardwood trees. Trust relationships between the local communities and other stakeholders participating in forest conservation and management activities have also been enhanced. It is recommended that to improve local communities' attitude towards conservation there is need to increase the flow of both direct and indirect benefits to the local communities thus creating strong partnerships for effective conservation and management of the forest.
\end{abstract}

Keywords: Forest Adjacent Communities, Forest Conservation, Fence, Attitudes, Mount Kenya

\section{Introduction}

Fencing has emerged as an alternative conservation and management strategy to control and regulate interactions between natural landscape resources and surrounding communities. Most conservation areas in Sub-Saharan region have diversified plants and animals and are partially or completely fenced to control the movement of wildlife out of the protected areas and unauthorized people into the areas [20] Most of times fencing and conservation of protected areas tend to be planned so as to separate natural landscapes from threatening human activities like illegal logging and poaching $[13,29]$. There are different types of fencing as described by [20]. Fencing has been implemented to meet multiple benefits and objectives ranging from ecological and protection of the habitats [5, 22] achieving management objectives like controlling the spread of invasive species [3]; controlling illegal killing of wildlife [4]; controlling and minimizing spread of diseases between wildlife, cattle and human beings $[30,32,8,12,29]$ and protection of infrastructure and controlling predation and competition for resources $[10,6]$ From social perspective, fencing has an opportunity to control human wildlife conflicts and reduce destruction of crops in agricultural areas which are found adjacent to most conservation areas $[25,23,20,11,15]$ Fence boundaries have also been established to exclude local people from collecting fuel wood and cutting fodder and grasses from protected areas [4].

Fencing in conservation and protected areas within Sub-Saharan region and Kenya has gained momentum for the last decade in controlling the problematic wild animals like elephants. In Kenya fencing and conservation on protected areas has been adopted in major wildlife habitats including national parks, private conservancies and communal lands. 
Some of the examples of fenced areas in Kenya include Meru National Park, Aberdares National Park [2] Amboseli National Park [17]; Lewa Wildlife Conservancy [13] and Ol Pejeta Conservancy in Laikipia [20]. Most conservation areas in Kenya are managed at different levels by national and county governments and private investors who have been able to establish private conservancies. To achieve conservation and management objectives there has been a tremendous effort to involve adjacent communities in decision making process. Research studies on attitude are thus useful in guiding policy interventions since they provide an understanding on acceptance and impact on conservation interventions [16]. Community attitudes are linked to long term existence and sustainability of protected conservation areas [7]. The attitudes of local communities who are adjacent neighbors of natural resources stock are thus critical to the success of conservation of management efforts like fencing [26]. Currently, Kenya has a supportive legal framework which recognizes the involvement of the communities living adjacent to protected conservation areas and other natural resources. The framework recognizes the participation and involvement of different stakeholders in conservation and management activities. Mount Kenya is managed through collaborative efforts involving multiple stakeholders at different levels. At both middle and lower levels, most notable stakeholders include; Kenya Wildlife Service (KWS), Kenya Forest Service (KFS) and Community Forest Associations (CFA). Whereas KWS and KFS are state led conservation agencies, CFAs are a conglomeration of different user and interest groups which are found within a defined geographical area of five kilometers from the forest boundary. CFAs are established under Forest Act 2007 and they provide a strong link between the government lead conservation agencies and the local communities.

Over the years conservation of Mount Kenya Forest has faced several threats ranging from destruction by illegal bhang growers and timber poachers, illegal grazing, invasive species, forest fires, poaching of wild animals and forest fires [16]. Local communities have also been facing challenges associated with human wildlife conflicts, loss of lives and destruction of croplands causing a lot of desperation to the local farmers. To address aforementioned challenges local communities in collaboration with other stakeholders proposed an electric fence to separate local communities and the forest. The fence was installed in 2015. However, no research has been done about the perceptions and attitudes on the local communities towards the impacts of fence on management and conservation of the forest.

This study was therefore carried out with an objective of assessing the local people's attitudes towards conservation and management of the forest and how fence installation has impacted or contributed to protection and conservation of the forest. This information shall provide necessary information to policy makers and stakeholders who are interested and involved in management of natural resources across the globe.

\section{Materials and Methods}

\subsection{Study Area}

The specific study site is Chuka Forest Station which is located in Tharaka Nithi County on the Eastern Slopes of Mount Kenya Forest and covers an area of 23,492 hectares; of which 192 hectares is plantation forest [16]. It lies within longitudes 37॰19'0" E, 37॰36'0" E and latitudes $0 \circ 11^{\prime} 0^{\prime \prime} \mathrm{S}$, $0 \circ 19 ' 30 " \mathrm{~S}$. The forest is surrounded by dense population of small scale farmers who normally grow both cash and food crops including dairy and livestock keeping. The study area is part of Mount Kenya Ecosystem which consists of a National Park and National Forest Reserve and serves as a Man and Biosphere Reserve and Global Cultural Heritage Site [21]. The Forest is an important water tower being a steady source of water for several permanent rivers within the region. As an Important Bird Area (IBA) it is a home of about 81 endemic bird species [16]. Therefore, the forest provides a range of ecological and economic benefits putting it at the top priority of conserved areas among major water towers in Kenya. It is home to several primates like black and white colobus (Colobus guereza) and Sykes monkey (Cercopithecus mitis), olive baboon (Papio anubis), the lesser bush baby (Galago senegalenses) and greater bush baby (Galago crassicaudatus) and mammals which include; African elephant (Loxodonta africana); Black rhinoceros (Diceros bicornis); White rhinoceros (Ceratotherium simum simum) and Mountain Bongo (Tragelaphus eurycerus isaaci) [16].

\subsection{Data Collection}

Data for this study was collected from a random sample of 100 semi structured questionnaires which were administered to the household heads, during the month of November and December 2017. The variables were; benefits from the forest and perceptions on various aspects of forest conservation and management. The respondents were drawn from a range of 0 to one kilometer from the fence/ forest boundary. Other vital information on forest destruction and illegal activities, forest patrols, improvement on forest conservation status was collected from secondary sources and relevant key informant like forest managers and leaders of the local community organizations like Community Forest Associations (CFA).

\subsection{Data Analysis}

The collected data was analyzed using Statistical Packages for Social Scientists (SPSS) and presented using various graphical techniques. Data was analyzed for descriptive statistics mainly frequencies and percentages.

\section{Results and Discussion}

\subsection{Socio-Economic and Demographic Characteristics of the Respondents}

From the findings, $57 \%$ of the respondents were male and $43 \%$ were female which gave almost an equal proportionate 
representation in the study. In relation to marital status, $94 \%$ were married while $6 \%$ had not married. In regard to age distribution, findings revealed that $6 \%$ of the respondents were between the ages of 21-30 years; $30 \%$ were between the ages of $31-40$ years; $24 \%$ between the ages of $41-50$ years; $19 \%$ were aged 60 and above. This implied that a majority of the respondents were within the ages of 31 years and above.

With reference to educational levels of the respondents, $6 \%$ had no formal education; $45 \%$ had primary education; $44 \%$ had secondary level education and $5 \%$ had studied beyond secondary school. This implied that most of the respondents had both primary and secondary level of education. It can therefore be assumed that majority of the respondents have a fair understanding of the matters relating to environmental conservation and development.

Economically, all the respondents practice small scale mixed farming. Most of the crops grown include the cash crops like coffee and tea; food crops like bananas, maize, arrow roots and vegetables. Other sources of income include livestock/ dairy farming 54\%; small scale business $10 \%$; formal employment $10 \%$. This implies that farming and livestock keeping are main sources of income in the area. This is justifiable considering the good soils and reliable rainfall due to the influence of Mount Kenya Forest. The average monthly income for the household is Ksh. 7352 which is equivalent 73.5 USD. In terms of land size, the average ownership is 1.5 acres and the respondents were drawn from edges of the forest to a distance of one kilometer from the forest boundary.

With regard to membership of local community groups; $56 \%$ of the respondents belonged to at least one local group whereas $44 \%$ did not belong to any group. The activities of the group ranged from agricultural based livelihood improvement projects like poultry keeping, goat rearing and natured based enterprises like bee keeping and establishment of trees nurseries. Most of these activities were either carried at individual or group level. Most of the groups are members of the local Community Forest Association (CFA), which has a responsibility of coordinating and participating in management and conservation of Mount Kenya Forest.

\subsection{Community Attitudes Towards Conservation and Protection of the Forest}

Regarding conservation and protection of the forest, $76 \%$ of the respondents do not support the de-gazettement of forest to create land for settlement and farming while $24 \%$ of the respondents supported de-gazettement of the forest land. From in-depth probing during the fieldwork, those who were against the practice feared that it would create more environmental related challenges like prolonged drought, drying of rivers and low crop yields. Research studies have shown that forest clearing can contribute to effects related to; climate change or modification of local climate [33, 24]; prolonged drought [19]; and drying of water courses [9, 14]. These changes can have profound effects to the local people whom the sole livelihood is dependent on agriculture. The forest also provides both direct and indirect benefits to the local people (Table 1).

Table 1. Importance of forest to the local people.

\begin{tabular}{ll}
\hline Forest product or service & $\%$ \\
\hline Fuelwood collection i.e. dead wood materials and branches & 98 \\
Timber & 74 \\
Food related products like vegetables, fruits, honey, salty water & 94 \\
Medicinal plant materials i.e. roots, barks or leaves, & 60 \\
Development projects like irrigation water projects & 21 \\
Recreational activities & 4 \\
\hline
\end{tabular}

Source: Fieldwork (2017).

After probing those respondents who supported de-gazettement of forest (24\%), the findings revealed that these people are motivated to acquire land for farming. This can be expected since most households have small land sizes of 1.5 acres but some have even less than 0.5 acres. The forest has also rich soils which are very ideal for agricultural activities. To explore the feelings of local peoples towards conservation and protection of the forest, the respondent were asked to rank three activities; protection of the forest, protection of the wildlife and development projects like water and schools. The findings revealed that most people ranked conservation of forest as the most important priority (Table 2). This is influenced by the amount of benefits that the respondents are getting from the forest [28, 1]. During the interview some respondents confirmed that they normally collect fuel-wood and fodder to sell in order to improve their livelihood.

Table 2. Ranking of Priorities by the local communities.

\begin{tabular}{lll}
\hline Ranking of priorities & Most Important & Important \\
\hline Conservation of the forest & $84 \%$ & $16 \%$ \\
Protection of the wildlife & $65 \%$ & $35 \%$ \\
Development projects like Irrigation projects & $64 \%$ & $36 \%$ \\
\hline
\end{tabular}

In regard to the satisfaction of the current streams benefit (both direct and indirect) accrued from the forest; $81 \%$ were both satisfied and very satisfied; $4 \%$ were neutral while $15 \%$ were dissatisfied. After probing during the fieldwork, dissatisfaction was caused by the fact that local people are not allowed to access the regulated forest products for free. 


\subsection{Management Strategies and Awareness of About the Fence}

From the research findings all the respondents had full information about the electric fence before installation at the edges of the forest boundary. Main sources of the information were from community sensitization and stakeholders meetings which were held across the villages by KFS, KWS and CFA. In regard to involvement, $76 \%$ of the respondents were involved during fence installation. Local people were mainly involved in clearing the fencing routes and attending meetings.
The common challenges that were faced by the local communities before installation of the fence include; crop damage by elephants, livestock predation and high levels of insecurity caused by gangs who could easily hide in the forest after committing crime. Most respondents felt that the above challenges have reduced significantly since the installation of the fence. The findings thus corroborates with [20, 23, 29] as far as minimizing human wildlife conflict is concerned. In respect to whether the fence will enhance conservation and protection of the forest, respondent had varied opinions (Table $3)$.

Table 3. Perceptions towards the fence by the local communities.

\begin{tabular}{ll}
\hline Will fence enhance conservation and protection of the forest? & \% \\
\hline No opinion & 4 \\
Strongly disagree & 11 \\
Neutral & 3 \\
Agree & 19 \\
Strongly agree & 63 \\
\hline
\end{tabular}

Source: Fieldwork (2017).

From in depth analysis during the household survey, most respondents cited some changes associated with installation of fence like; expansion of farming activities; improved security in the area; reduced forest illegal activities, reduction of crop damage by elephants and reduced risk to human life [27]. This was further corroborated with secondary information which was collected during the field work (Figure 1). The study shows that fence was effective in reducing crop damage and destruction of crops and property by large animals like elephants. However, during the fieldwork it was observed that cases of fence destruction were increasingly caused by trees and branches that were falling off [27]. This may require regular clearing and monitoring to make fence more effective.

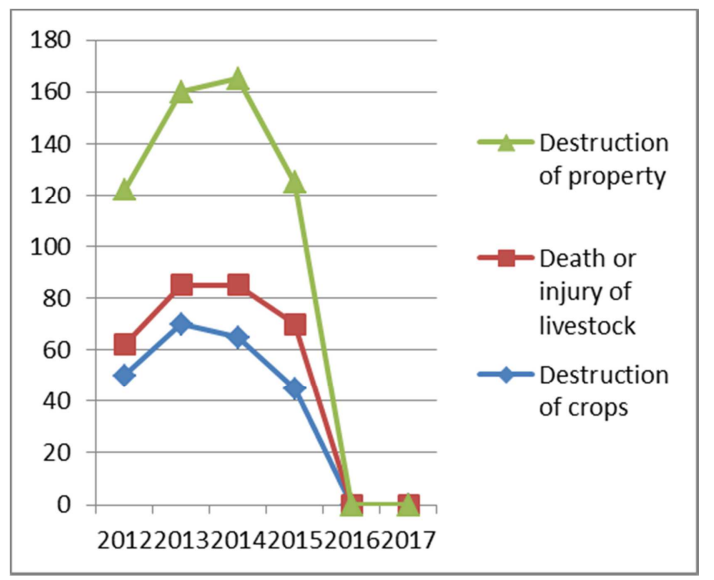

Figure 1. Effects of fencing damage on crops, property and death of livestock.

\subsection{Effects of Fencing on Forest Conservation}

Fencing plays a significant role in protecting natural landscape and preventing loss of species from protected areas [5]. This would only be achieved if destructive activities are minimized or controlled from taking place within a protected area. Findings from the study indicate that installation of the fence has had a significant impact towards the reduction of illegal activities like cultivation of bhang, poaching of hardwood and setting of animal traps (Figure 2). However, it is important to note that in spite of the installation of fencing the search for precious indigenous trees like camphor is still high.

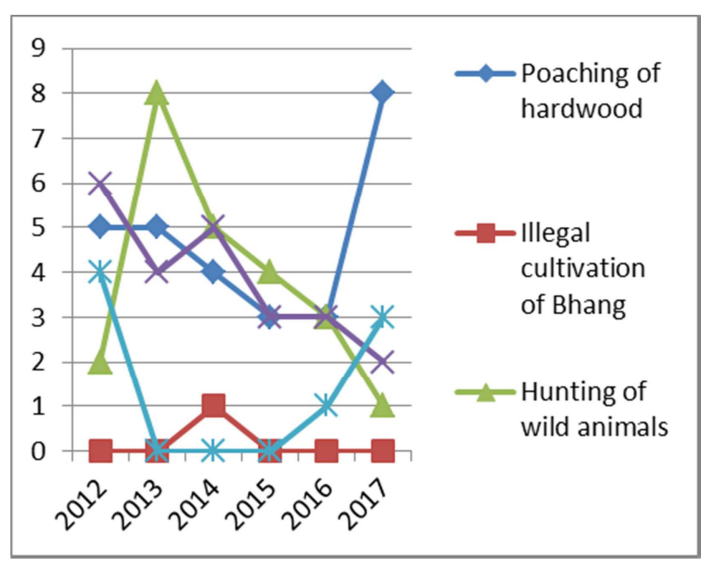

Figure 2. Effects of fencing on forest illegal activities.

Further review of secondary information indicated that the cases of arrests have declined after installation of the fence (Figure 2). This gives a positive index towards protection and conservation of the forest. Interviews with forest officials indicated that other than decline in illegal activities, the forest cover has improved since most of the old paths in the forest have closed.

\subsection{Trust and Relationships Between Stakeholders}

Trust amongst the institutions is important in increasing community participation and enhancing conservation attitudes [31]. The forest is managed through collaborative efforts amongst stakeholders and interested parties from both government and non-governmental entities. Findings show that $92 \%$ of the respondents were aware of the institutions that 
are involved in management of the forest, while $8 \%$ did not have prior information. Some of the institutions that were mentioned to have directly or indirectly been involved in the management of the forest include; Chuka CFA, Kenya Forest Service, Kenya Wildlife Service, Green Belt Movement and Rhino Ark. However, during the interviews it was noted that most respondents could not differentiate the roles and responsibilities of different institutions. Findings show there is varied level of trust between the communities and different institutions that are actively involved in forest conservation and management (Figure 3). This gives a strong indicator of a successive partnerships and positive attitudes towards conservation activities within the forest.

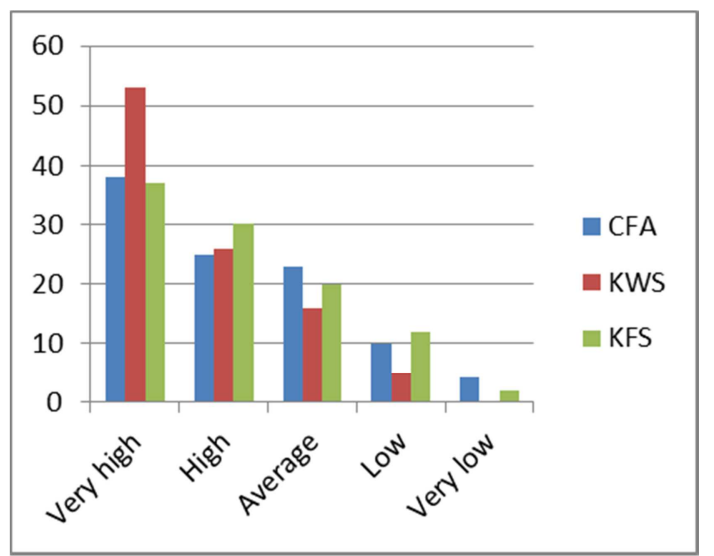

Figure 3. Relationship between local communities and institutions.

\section{Conclusion}

This study has provided evidence that fencing as a management tool has contributed significantly towards enhanced forest protection and conservation.. Fence as a management tool has the ability to reduce crop destruction and damage to property by mammals like elephants. Specifically, the study has shown that benefits from the forest are diverse and have significant influence on community attitudes towards conservation, protection and management of the forest. Further, the study shows that awareness and sharing of information is important in improving the trust and relationship between stakeholders, which is a catalyst towards successful conservation, protection and management of natural resources like forest.

\section{Conflicts of Interest}

The author declares that there are no conflicts of interest regarding the publication of this paper.

\section{Acknowledgements}

The author would like to acknowledge and appreciate the research assistant Mr. Stephen Munuhe, officials from Kenya Forest Service, Chuka and leaders of Chuka Forest Association for making this research successful.

\section{References}

[1] Arjunan, M., Holmes, C., Puyravaud, J. P., \& Davidar, P. (2006): Do developmental initiatives influence local attitudes toward conservation? A case study from the Kalakad-Mundanthurai Tiger Reserve, India. Journal of Environmental management, 79(2), 188-197.

[2] Boone, R. B., \& Hobbs, N. T. (2004): Lines around fragments: effects of fencing on large herbivores. African Journal of Range and Forage Science, 21(3), 147-158.

[3] Brooks, M. L., D'antonio, C. M., Richardson, D. M., Grace, J. B., Keeley, J. E., DiTomaso, J. M. \& Pyke, D. (2004): Effects of invasive alien plants on fire regimes. BioScience, 54(7), 677-688.

[4] Büscher, B. (2010): Anti-politics as political strategy: Neoliberalism and transfrontier conservation in southern Africa Development and change, 41(1), 29-51.

[5] Caro, T. M. \& Scholte, P. (2007): When protection falters. African Journal of Ecology, 45, 233-235.

[6] Cavalcanti, S. M., Crawshaw, P. G., \& Tortato, F. R. (2012): Use of electric fencing and associated measures as deterrents to jaguar predation on cattle in the Pantanal of Brazil. In Fencing for Conservation (pp. 295-309). Springer, New York, NY.

[7] Dewu, S., \& Røskaft, E. (2017): Community attitudes towards protected areas: insights from Ghana. Oryx, 1-8.

[8] Foggin, J. M. (2008): Depopulating the Tibetan grasslands: national policies and perspectives for the future of Tibetan herders in Qinghai Province, China. Mountain Research and Development, 28(1), 26-31.

[9] Foley, J. A., Asner, G. P., Costa, M. H., Coe, M. T., DeFries, R., Gibbs, H. K., \& Snyder, P. (2007): Amazonia revealed: forest degradation and loss of ecosystem goods and services in the Amazon Basin. Frontiers in Ecology and the Environment, 5(1), 25-32.

[10] Grant, C., Bengis, R., Balfour, D. \& Peel, M. (2007): Controlling the distribution of elephants. The 2007 scientific assessment of elephant management in South Africa. (eds. Mennell, K. \& Scholes, R.) Witwatersrand University Press, Johannesburg

[11] Hall, S. (2013): Launch of the Akagera fence by the Rwanda Development Board. African Park Latest News. African Parks, www.african-parks.org.

[12] Hayward M W. 2012: Perspectives on fencing for conservation based onfour case studies: Marsupial conservation in Australian forests; bushmeat hunting in South Africa; large predator reintroduction in South Africa; and large mammal conservation in Poland. In:Somers M J, M W Hayward (Eds.). Fencing for Conservation: Restriction of Evolutionary Potential of a Riposte to Threatening Processes? New York: Springer, 7-20.

[13] Hayward, M. W., \& Kerley, G. I. (2009): Fencing for conservation: restriction of evolutionary potential or a riposte to threatening processes. Biological Conservation, 142(1), 1-13.

[14] Hesslerova, P., \& Pokorny, J. (2010): Forest clearing, water loss, and land surface heating as development costs. International Journal of Water, 5(4), 401-418. 
[15] Kesch. M. K; Bauer D. T \& Loveridge A. J. (2015): Break on through to the other side: the effectiveness of game fencing to mitigate human-wildlife conflict. African Journal of Wildlife Research 45(1): 76-87

[16] Kenya Wildlife Service (2010): Mt Kenya Forest Ecosystem Management Plan, 2010-2020.

[17] Kideghesho, J. R., Røskaft, E., \& Kaltenborn, B. P. (2007): Factors influencing conservation attitudes of local people in Western Serengeti, Tanzania. Biodiversity and Conservation, 16 (7), 2213-2230.

[18] Kioko, J., Muruthi, P., Omondi, P., \& Chiyo, P. I. (2008): The performance of electric fences as elephant barriers in Amboseli, Kenya. South African Journal of Wildlife Research, 38(1), 52-58.

[19] Laurance, W. F., \& Williamson, G. B. (2001): Positive feedbacks among forest fragmentation, drought, and climate change in the Amazon. Conservation Biology, 15(6), 1529 -1535 .

[20] Lindsey, P. A., Masterson, C. L., Beck, A. L., \& Romañach, S. (2012): Ecological, social and financial issues related to fencing as a conservation tool in Africa. In Fencing for conservation (pp. 215-234). Springer, New York.

[21] Nyaligu, M. O., and Weeks, S. (2013): An elephant corridor in a fragmented conservation landscape: preventing the isolation of Mount Kenya National Park and National Reserve. Parks, 19(1), 91-101.

[22] Norton-Griffiths, M. (2007): How many wildebeest do you need? World Economics, 8, 41-64.

[23] Ogada, M. O., Woodroffe, R., Oguge, N. \& Frank, L. G. (2003): Limiting depredation by African carnivores: the role of livestock husbandry. Conservation Biology, 17, 15211530 .

[24] Ojima, D. S., Galvin, K. A., \& Turner, B. L. (1994): The global impact of land-use change. BioScience, 44(5), 300-304.
[25] Osborn, L. \& Anstey, S. (2002): Elephant/human conflict and community development around the Niassa Reserve, Mozambique. WWF-SARPO Report. Internet

[26] Robertson, J., \& Lawes, M. J. (2005): User perceptions of conservation and participatory management of IGxalingenwa forest, South Africa. Environmental Conservation, 32(1), 64-75.

[27] Sapkota, S., Aryal, A., Baral, S. R., Hayward, M. W., \& Raubenheimer, D. (2014): Economic analysis of electric fencing for mitigating human-wildlife conflict in Nepal. Journal of resources and ecology, 5(3), 237-243.

[28] Sekhar, N. U. (2003): Local people's attitudes towards conservation and wildlife tourism around Sariska Tiger Reserve, India. Journal of environmental Management, 69(4), 339-347.

[29] Somers, M. J. \& Hayward, M. W. (2012): Fencing for Conservation: Restriction of Evolutionary Potential or a Riposte to Threatening Processes? Springer, New York, NY.

[30] Stutmoller, P. (2002): The fencing issue relative to the control of foot-and-mouth disease. Annals of the New York Academy of Science, 969, 191-200.

[31] Thakadu, O. T. (2005): Success factors in community based natural resources management in northern Botswana: Lessons from practice. In Natural Resources Forum (Vol. 29, No. 3, pp. 199-212). Blackwell Publishing, Ltd.

[32] Thomson, G., Tambi, E., Hargreaves, S., Leyland, T., Catley, A., van't Klooster, G. \& Penrith, M. (2004): International trade in livestock and livestock products. Veterinary Record, $155,429-433$.

[33] Tinker, P. B., Ingram, J. S., \& Struwe, S. (1996): Effects of slash-and-burn agriculture and deforestation on climate change. Agriculture, Ecosystems \& Environment, 58(1), 13-22. 